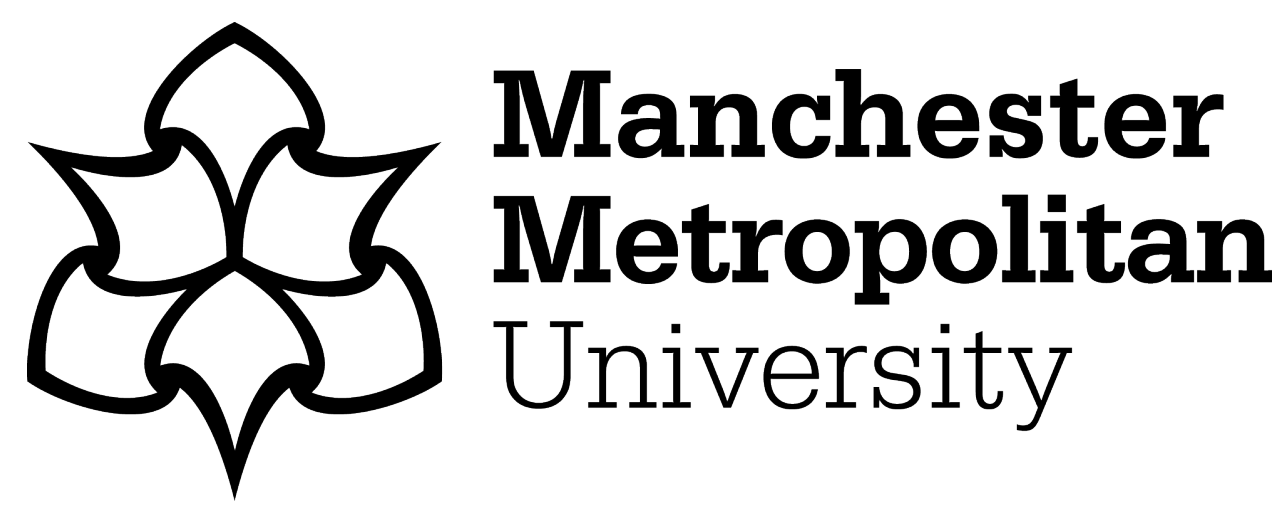

Benozzo, A, Pizzorno, MC, Bell, $H$ ORCID logoORCID: https://orcid.org/0000-0002-9695-9632 and Koro-Ljungberg, M (2015) Coming out, but into what? Problematizing discursive variations of revealing the gay self in the workplace. Gender, Work and Organization, 22 (3). pp. 292-306. ISSN 0968-6673

Downloaded from: https://e-space.mmu.ac.uk/307/

Version: Accepted Version

Publisher: Wiley

DOI: https://doi.org/10.1111/gwao.12081

Please cite the published version 


\title{
Coming out, but into what? Problematizing discursive variations of revealing the gay self in the workplace
}

\begin{abstract}
There is a substantial mainstream literature on coming out in organizations, which investigates the positive effects for gay people of being out at work, but very few contributions that challenge the discourse of coming out. Taking as its starting point Butler's famous question 'So we are out of the closet but into what?', this paper problematizes coming out discourses in the workplace. We report on a study in which ten men were invited to talk about their coming out in the workplace. There were three main ways through which our participants constituted themselves as gay men when they talked about coming out: by defining themselves as, and admitting to, being gay; by introducing themselves as being in a gay relationship; and by adopting legitimate subject positions such as the Other, the different one, or the normal gay. Through our analysis, discussions and conclusions we show how participants position themselves within different discursive variations thus revealing multiplicity of 'the gay self' and highlighting how coming out repeat and support normative systems.
\end{abstract}

Key words: coming out, workplace, gay men, heteronormativity, homonormativity. 
This paper is intended to problematize the discursive variations used by our research participants when disclosing their gay identity in the workplace. The aim of our study is to challenge received wisdom, and to capture the complexity and the problematicity of discourses of coming out in the workplace. By using the expression discursive variations we underline the recursive nature of coming out, since meeting a new colleague, for example, or changing jobs, necessitate a repetition of the disclosure. We will highlight how coming out, far from being a liberating and emancipating act, represents an entrance into problematic discursive variations that limit the expression of identity, have a regulating effect on the lives of individuals, and reinforce the privileged position of heterosexuals.

The inspiration for this paper lies in the famous question posed by Butler in Imitation and Gender Insubordination: 'So we are out of the closet but into what?' (1991: 16). In her essay she problematized the discourse of coming out because declarations of gay or lesbian identities constitute a precondition for new closets: 'For being 'out' always depends to some extent on being 'in'; it gains its meaning only within that polarity. Hence, being 'out' must produce the closet again and again in order to maintain itself 'out' (1991: 16). According to Butler coming out establishes and reinforces the hetero vs homo binarism, creating a relationship of power between straight and gay; moreover, 
the construction of social categories such as hetero and homo implies subordination and subjection to regulatory discourses. Coming out is also problematic, we would add, because it buttresses the inequality between straights and gays: heterosexuals enjoy the privilege of not having to declare their sexual identity; unless you come out, it is assumed that you are straight. Our position is that coming out does not necessarily produce beneficial effects for non-heterosexuals, and that workers and researchers could benefit from a study of coming out that analyzes the regulatory discourses that shape it and discusses the moral and ontological implications.

We would like see more studies involving all minority groups, since contemporary society continues to in one way or another perpetuate anti-discriminatory discourses against all such groups (including racial, lesbian, bisexual, and transgender groups). However, in this study we focus only on gay men for two reasons: first, it allows us to concentrate on the contextual and situational factors of one clearly delineated subgroup; second, our focus on a small group of participants enables us to pay attention to and value the features peculiar to each participant while preserving the nuances of their language, We do not consider the coming out discourses used by the participants in our study representative of LBT people or of other gay men, thus other research in this field is needed. The article is structured as follows. First, we briefly describe how coming out is studied in the literature on sexual minority disclosure in the workplace and then put forward our theoretical framework. There follows a presentation of our research, a 
description of the methodology and the data analysis through discourse analysis. The findings of the research are presented via emblematic cases, which reveal the principal discourses used when people talk about their coming out in the workplace. In our conclusions we consider the most important contributions to emerge from the study.

Sexual minority disclosure in the workplace

The topic of coming out is one issue in the literature on sexual minority orientation and disclosure in organizations. The mainstream approach to sexual minority disclosure in organizations focuses on the strategies which individuals adopt in disclosing (or otherwise) their sexual identity, outlining the factors which hinder or facilitate disclosure, and also the consequences which this disclosure has for the individuals and for the organization (Button, 2004; Clair et al., 2005; Croteau et al. 2008; Douglas et al., 2011). Some research projects have identified the factors which facilitate disclosure, such as anti-discrimination policies and an organizational climate of inclusivity (Bouzianis et al., 2008; Griffith and Hebl, 2002). The literature on sexual minority orientation and disclosure underlines the positive outcomes of the process of coming out for the individual, in terms of empowerment, happiness and confidence (Colgan et al., 2008; Day and Schoenrade, 2000), or in terms of greater satisfaction at work, psychological commitment, and experiencing less organizational conflict (Day and Schoenrade, 2000; Ward and Winstanley, 2003). 
We think mainstream approaches have three limitations. First, the results of these studies on the positive effects of coming out are uncertain; despite the emergence of gay friendly organizations (Colgan et al., 2007; 2008) there is a broad swathe of literature which testifies to the presence of discriminatory behaviours (Colgan and Wright, 2011) and homophobic discourses towards sexual minorities within organizations (Ozturk, 2011; Willis, 2012).

Secondly, mainstream literature is based on the tacit assumption that coming out has an empowering effect on the individual and on the organization. It is the idea that coming out has the power to fight prejudice and, as such, it is right and opportune to come out. What is at stake here is a belief that coming out has, in and of itself, the potential to produce change in colleagues (if gay people come out, heterosexual colleagues will change their prejudices towards homosexuals and homosexuality). We want to problematize this particular interpretation and the rhetoric that advocates the value of coming out. This rhetoric, which found its roots (Grass, 2001; Sullivan, 2003) at the end of the sixties in the well known Stonewall events in the US and the Gay Liberation Front ${ }^{1}$, has resonated again recently in a book written by Browne ${ }^{2}$ (2014) with the significant

\footnotetext{
${ }^{1}$ As Sullivan (2003) explained: “... one could argue that the four key concerns shared by the majority of (liberationist) activists and organizations [in the USA] were Pride, Choice, Coming out, and Liberation" (p. 29).

${ }^{2}$ Lord Browne was the CEO of BP between 1995 to 2007. In his autobiography he describes his experience as a top manager who lived in the closet. The Guardian commenting on his book writes: 'By the time attitudes in Britain began changing in the 90s, Browne had been living a lie for so long that the deceit itself had become as much of a secret as his sexuality, and the prospect of disclosure even more unthinkable. "You invest in the duplicity to the point where you can't disinvest. You know, it just builds one layer on
} 
title The Glass Closet. Why Coming Out Is Good Business. In organizational settings which support the rhetoric of out and proud, those who successfully come out become role models for the promotion of tolerance and inclusiveness ${ }^{3}$. Against this, those who do not succeed or do not want to come out may feel cowardly, өr failures, dishonest or not transparent. One consequence of this process is the creation of a hierarchy system between those who come out and those who do not (Gusmano, 2008).

The third limitation of these studies is ontological, since they continue to use an identity category and, more generally, analytical categories of difference (such as homosexual and heterosexual, male and female, black and white), and therefore reinforce the idea that these dichotomous categories are non-problematic and possess their own ontological fixedness (Prasad, 2012). However, the poststructuralist theories that inform this study argue that identity is unstable, uncertain, and always changeable, depending on the position the subject takes up within the discourses (Ford, 2006).

Coming out in the workplace as a performative act

Our theoretical framework draws on discourse analysis and poststructuralist theories

another and then the time is never right. So how do you back out of it? The answer is, you have to take one step. If in doubt, come out. But come out early, before you've made this investment." The key, he argues, is to make it easy for gay employees to come out at the beginning of their careers' (The Guardian, http://www.theguardian.com/society/2014/may/24/lord-browne-thought-being-gay-wrong-interview-bpboss-homophobia, July the 31st 2014).

${ }^{3}$ See the annual Survey by the UK organization Stonewall (i.e. The Stonewall 100. The Workplace Equality Index), which emphasizes the importance of the presence of persons who come out of the closet and serve as role models in workplace. 
(Britzman, 2000; Butler, 1999; Foucault, 1976) and implies a conception of the subject as constituted by discourses which define what we can or cannot be - a woman, a man, a lesbian, a gay, a worker, a mother, a father - and what those who speak through those discourses consider truth, knowledge, value, intelligible speech and normal behaviour (MacLure, 2003). Poststructural perspectives understand coming out as a performative act, at one and the same time locutionary, illocutionary and perlocutionary (Austin, 1962; Butler, 1997a; Chirrey, 2003; 2011), which in consequence produces certain effects. Through this speech act the subject constructs the homosexual identity "... performatively enacted through the subject position made available to us in language or cultural code" (Ford, 2006, p. 80). In other words, when, for example, a worker states 'I'm gay' in front of a colleague, he uses an identity discourse, and at the same time creates an identity which did not exist before the coming out started, that is before for example our interviewees entered a room, met a colleague and came out. Coming out constitutes homosexual identity, although it is not a single event. Encountering a new colleague, a new workplace, a new boss, because of heteronormativity (Warner, 1993; Chambers, 2007) at work, lays the foundations for a new closet to be built, for the repetition of the coming out and of discourse variations. As Ward and Winstanley assert (2003), coming out has within itself paradoxical elements. Through coming out people do leave behind them the silence of invisibility - the absence of power - but they also position themselves once more within a situation of depowerment in view of the 
hierarchical relationship present in the heterosexual/homosexual binarism. The impotence of the silence of the closet does not disappear, it is transformed into subjection to (heteronormative or homonormative) discourses.

Following Butler, we view our data on coming out as performative acts and the language used by interviewees as a social practice that 'does not reflect the intention (or action) of the individual; language produces the discursive possibilities of performance and therefore the "doer" becomes an effect of the language' (Jackson and Mazzei, 2012: 68). Performative acts are conditioned by regulatory discourses that shape identity formation and subjects' normative and repeated behaviours.

The research

Data collection

The data derives from research involving ten gay men working in Manchester (UK). The participants were recruited through snowball sampling and through the Manchester LGB Foundation's monthly newsletter. As a result of this process, only Caucasian gay men belonging to the professional middle-class were recruited. Coming out in the workplace certainly operates jointly with other categories/differences (such as gender, race, religion, ethnicity and physical ability) (Taylor et al., 2010). We recognize that our study has 
addressed mainly race and religion differences because these differences were highlighted in this data. Thus, the intersectionality of gender, race, ethnicity, religion and so on creates different variations and contextual linkages in other data and among other participants. The context of our sample (white male middle-class participants) in this research highlights some interesting discursive variations and inevitably occludes others.

The interviews began with an invitation to the participants to discuss their occupations and the organizations in which they worked, exploring workplace sensitivities towards matters of sexual identity. Then the participants were asked to talk about their coming out in the workplace, and were prompted to recall the language and words used. Our perspective on interviews draws on the postmodern sensibility (Gubrium, Holstein, 2003; Roulston, 2010), in which 'interviewing is viewed as a social setting for the proliferation of polyphonic dialogues, in which there are many voices and discourses that cross each other simultaneously to produce knowledge about personal narratives and social life' (Tanggaard, 2009: 1500). Our data is obviously not an exact or fixed reproduction of the words used by a person when coming out, nor was this study concerned with recording the exact words used by interviewees. Our interest, rather, focuses on temporary discursive construction of the coming out in the current occupational setting or in previous workplaces. Furthermore, a postmodern view has led us to focus on the fact that the interviewee was performing a scene of coming out with the researcher. The data may also be read as the interviewee's testimony of coming out to 
the researcher and as the interviewee's response to researcher's position of power, and sexual, cultural and ethnic identity.

\section{Data analysis}

For the data analysis, we have drawn on Discourse Analysis (DA) (Gee, 2011; Parker, 2005). Through DA we analyzed the discursive variations of the participants' coming out that, on the one hand, placed the subject in positions of power and, on the other, justified and legitimated the position, which they assumed. This in turn constructed a community of consensus (or dissent) in relation to homosexuality.

First all data were transcribed verbatim and read multiple times. More specifically, our DA included three interlaced levels. The first level is represented by the analysis of the language and word choices used by the interviewees. During DA it is important to become sensitized to specific words because it is often through a common language that the subjects of the discourse are constituted. Additionally, DA invites researchers to go beyond the ordinariness of the participants' statements to emphasize the differences in the various linguistic and discursive constructions. These linguistic and discursive constructions can be located and described within both participants' and researchers' social contexts. In other words, discursive formations and structures can relate to the participants and researchers' social worlds and to their independent readings of linguistic markers. Discourses constitute the speakers but speakers also constitute the discourses. 
During the second level of analysis we identified different discourses that shaped participants' stories of coming out. This allowed us to identify the discursive variations, which characterized coming out, as well as the subject positions participants offered. By subject positioning, we refer to the 'location for persons within a structure of right and duties' (Davies and Harré, 1999: 35), and also the position of power which individuals assume when talking about their coming out in the workplace. Lastly, the third level of analysis focused on the ways in which individuals reproduced (or challenged) beliefs and normative systems present in the broader social context.

In the following section, through a selection of interview examples more relevant for our arguments, we present three ways of constructing and describing a nonheterosexual identity, as well as the discourses which shape coming out ${ }^{4}$. The data presented were chosen because they provided a cross section of the discourses of coming out in the workplace and they highlight some risks and limits of these discourses. Our findings do not merely refer to the occupation of the participants at the time of the project. The interviewees related those experiences of work (past and present) which had had the most significant effect on their careers. For this reason, we will examine experiences of coming out referring both to the current occupations of the interviewees, and to those past ones which had proved particularly significant. The interview extracts which we present are not replies to the specific question 'will you tell me about your coming out in the

\footnotetext{
${ }^{4}$ Data from all participants were analyzed and the quotations were chosen for their illustrative value.
} 
workplace?', but rather excerpts of the conversation between the interviewee and the interviewer focused on the subject of coming out in the workplace, which help to focus on the discursive variations and the subject's positions.

Our readings of this data put forward one potential interpretation highlighting experiences with 'coming out'. Scholars from other perspectives are likely to offer a different readings and interpretations of the empirical material we present. As in many qualitative research practices, culturally situated interpretations of the researchers can open up possibilities to work creatively with data intentionally avoiding one right, exact and most appropriate way to read, analyze, interpret, or make sense (Denzin and Lincoln, 2011).

Discursive variations in coming out in the workplace

\section{Coming out, but into what? Into a gay identity}

The first variation is the identity discourse of Nigel, a prison chaplain, of Peter, a health care assistant, of Harry, the manager of the conservatory, of Thomas and Brian, both working at a university as librarian and researcher respectively. The identity discourse was the most common between our participants. Here, we have chosen to present Nigel's case because it highlights well the power and context of this discursive variation. In a previous organization he had been a victim of harassment, at his interview with the HR manager Nigel needed to describe what happened to him: 
So I went through the story [...] of what had happened in that previous job ... and I said 'You know for me, being gay is a fundamental part of my identity, it's something I think about much of the time, and I'm not willing to pretend that I'm not gay, is this an issue for you?' And he said it was absolutely not an issue...

Nigel, while telling the HR manager 'I'm not willing to pretend that I'm not gay', is also saying 'I'm gay' (or 'I'm not straight'). From a poststructural viewpoint, these utterances ('I am gay' or common variations thereof, such as 'being gay' or 'I was out as gay') produce the identity but also the illusion that there exists a gay me or a gayness (Sedgwick, 1990). Nigel's identification with the gay identity category constitutes him as being a subject who can enter into relations with others (here, the HR manager); he reproduces the identity discourse and becomes recognizable and intelligible to his colleague. He obtains a sort of 'identity card': this is the performative effect of calling oneself gay. The word gay causes him to exist: this is the divine power of naming Butler (1997b). Nigel's comment that 'being gay is a fundamental part of my identity', highlights this as a central nucleus and fulcrum of one's very existence. And Nigel's phrase offers an opportunity to observe how gay subjectivity is produced by assuming the gay category as an internal object on which to reflect, to observe constantly -'I think 
about it much of the time'- until what might be an optical illusion becomes real, a true Self. Once objectified and examined in minute detail, the gay Self can no longer be betrayed and the individual commits to authenticity ('I'm not willing to pretend').

Nevertheless, defining oneself as gay has a considerable downside: the acceptance of guilt. During the interview Nigel goes back in time and evokes a period studying theology at university when he lodged in a boarding house for monks where:

... privately you could admit to them that you were gay and they would support you. They would try to point you in terms of stable relationships. It wasn't acceptable to sleep around or be promiscuous but they were very, very supportive.

Here a guilt-provoking identity discourse is at play. Nigel does not only define himself as gay, he also admits it as if it were a wrong. Identity categories, actually, are not neutral: being called, or calling oneself, gay involves registration in a binary, asymmetric system - hetero vs gay - in which the second term is subordinate and devalued; it is equivalent to an insult (Butler, 1997a). While Nigel remembers that youthful coming out in positive terms, thanks to the support received from his superiors, when he uses the expression 'admit to being gay', he consents to an identification of gay identity as guilty. According to Butler (1997b), in order to become a subject and to enjoy 
an identity in the eyes of the normative system, individuals must accept their guilt, and in this way they also become complicit with heteronormative law and allows heteronormativity to continue to intervene and to control: it is the heteronormative system that monitors in order that the exceptions to the norm be declared and made known. This interview also reveals how this newly-born gay identity must pay a second price: Nigel can be gay, but only in a stable relationship, without 'sleeping around' and without promiscuity; implicitly he will have to conform to a monogamous relationship.

Moreover, complicity with heteronormativity, enacted by adhering to the gay identity category, makes it possible not only to become intelligible to others, but also to oneself through the making of a true Self. The discovery of the Self might even allow one to function better than someone who cannot find that Self. In the course of the interview Nigel will say:

I feel far more integrated, far more together as a person, because I can actually say that, who I am and what I am and I don't feel that it's negative or bad, and I think it allows me to function better as a human being...

However, acceptance of the category gay leads the subject to mistakenly believe that identity 'is under the control of the individual, that human beings have an authentic sexual and psychological self which can exist outside of social control and cultural 
pressure' (Dow, 2000: 135). In other words, the identity discourse that shapes coming out introduces the subject to other domains of power, for example those of psychological or sexual discourses and practices, which produce recognizable, adapted, and self-controlled identities.

\section{Coming out, but into what? Into a gay couple relationship}

The second way of coming out is that of introducing oneself as being in a gay couple. When Mike and Roger recalled their comings out they departed from the classic formula of disclosure and availed themselves of the discursive variation of the gay couple relationship, positioning themselves as partners or as boyfriends. Mike related a period of his career when he was working in a haulage company and adopted an unplanned strategy of coming out to female colleagues: 'I didn't think of it [as coming out]'. It is an example of a coming out which follows the flow of the conversation, seeking to play down the drama of the disclosure and to defuse the emotional charge:

... when I would speak about my life which supposed the presence of a partner of the same sex... I would also speak about my relationships and I would say, for example, my boyfriend instead of my girlfriend... No, there has never been a dramatic point... 
Mike's utterance places him right in the position of the homosexual Other. The positioning of the partner as boyfriend violates, perhaps, the heteronormative expectation of his female colleagues, and at the same time violates the heterosexual matrix which welds together sex, gender and desire (Butler, 1999). Nevertheless, the violation is only apparent, since the matrix is implicitly reinforced as norm and rule. Welding together biological sex, gender and sexuality (I am a man and I have a boyfriend, therefore I am gay) is a homonormative discourse performed within a homosocial and predominantly female setting. Mike adds that he has 'never had a negative reply', and that 'he used to prefer to speak [of his boyfriend] with the women'. Female workmates are a less threatening audience than male heterosexual colleagues, who 'play football', an activity in which Mike was not involved. In this scene the friendship of a gay man with female colleagues is re-evoked within a homosocial work environment and brings to mind a heterosexual couple, desexualized and thus non-threatening for both the women and the $\operatorname{gay}(\mathrm{s})$.

Disclosure of one's homosexuality coincide with the account of life with a boyfriend, revealing scenes of a life in a couple, illustrates the use of discursive strategy to unite language and social strategy used also by Roger, who in his tale of coming out at a law firm, recalls the grief of separation from an important person which caused his absence from work for some days. Here, Roger entrusts the task of revealing his sexual identity to one of the heterosexual manager, who gets across Roger's pain to the other 
boss with recourse to the image of the heterosexual couple:

I think I took a couple of days off and my boss apparently had complained ... one of the other bosses had said to him 'just imagine your wife walked out ... [T]he person who's walked out of his life is as important to him as your wife is [to you ] ... this was the love of his life who's left him ...

The couple's relationship is circumscribed by a romantic discourse ('this was the love of his life') in which Roger's suffering over the separation is presented by comparison with the story of a heterosexual couple, where often the one left is also distraught and overcome with pain. Skidmore (2004) has highlighted how one of the effects of heteronormativity in work settings coincides with the fact that in the moments of separation, non-heterosexuals receive less support from their colleagues than heterosexuals. This episode presents a situation in which Roger's suffering seems to find a space to take it in, but at the same time Roger is subjected to those discursive practices according to which gay couple relationships replicate the same couple dynamics as the heterosexual couple. The use of the two words, boyfriend and partner, mark the entry into discursive regimes. For example, boyfriend transforms the heterosexual matrix into a homosexual matrix and thus confirms the hetero/homo binarism. The word partner opens up a relational landscape, which can also connect with the economic world; the partner is 
he/she with whom business interests are shared, and thus the relationship is constructed within a discourse in which the partners are connected, interdependent and somewhat bound. On a broader level, partner is problematic both for gays and for heterosexuals; it produces a gender ambiguity because it 'foils the opposite-sex spouse presumption built into heteronormativity' (Chambers, 2007: 674-675). Some organizations, for example, universities, which have constructed working environments based on the use of the word partner seem to have made only a small step forward in challenging the presumption of heterosexuality, and it happens that in conversations in which partner is used very often the term must be disambiguated by specifying the pronoun he or she.

In addition, if in the case of Mike, the formula of coming out seems to be coming out of the drama of disclosure, at the same time it displays disciplining problematicity at the moment the subject models and presents his life, centring it on the image of the homoerotic couple. This is what Ryan, another interviewee, is alluding to saying when he states:

'You know you don't talk about sex or something like that. You just talk about what you are doing with your boyfriend at the weekend or where you are going on holiday or something like that, it's fine'.

We may here remind ourselves of the reflections provided by feminist critiques 
(Duggan, 2002; Strycker, 2006) on new neo-liberal homonormativity defined as a politics that 'does not contest dominant heteronormative assumptions and institutions but upholds and sustains them while promising the possibility of a demobilized gay constituency and a privatized, depoliticized gay culture anchored in domesticity and consumption' (Duggan, 2002: 622). As these feminist scholars have emphasized, in discourses on the relationship of the couple, the respectable gay coincides with the white man, belonging to the middle class, who takes particular care of his image and of his physical appearance, who is financially independent and tells of a life in a couple modelled around that of monogamous heterosexuals. The gay who in the workplace is respectable is in harmony with the norms and rules relating to gender, to social class, to race and to the cultural background which more generally constitute the 'ordinary' citizen. And we also believe that the discourses linked to the spread of gay marriage (in those countries in which it can now or may in future take place) could reinforce homonormativity: same-sex couples can (or may in the future) make use of the entire range of discursive variations already available to heterosexual families to speak of themselves, their children and their families in the workplace, so reinforcing the regulatory discourses of family and private life. The risk is that these discourses come to represent a form of regulation of lesbian and gay subjectivity, which excludes and renders any expression of queer promiscuity (Richardson, 2004) or precarious sexualities (Woltersdorff, 2011) tame. These reflections introduce us to the final discursive variation in which the themes of the good gay return, 
expressed in the formula of 'the different' and 'the normal' gays.

Coming out, but into what? Into the 'different' or 'normal' gay man

The third way of coming out is by identifying oneself as the different gay or as the normal one. In presenting this we will return to the case of Nigel, the prison chaplain encountered in the first discursive variation, and then we shall meet John, manager of a fast food restaurant. During the conversation with Nigel we sounded out the idea of imagining coming out to an imam, a colleague, to whom Nigel has not revealed his homosexuality. In this fantasy coming out, Nigel reconstructs his colleague's family background, one in which the woman does not work and devotes herself totally to her working husband's needs. He describes the classic patriarchal family, where the husband is the authority figure, in complete charge of a wife who must take care of the needs of her husband and children, and not by chance Nigel mentions that what the imam ' $\ldots$ is interested in [is] in who does the domestic work [for Nigel]... he finds it very difficult to understand how I can cook and clean and look after myself'. According to Nigel, his Muslim colleague doesn't know 'what a gay person is ... I think he probably thinks that gay men are the same as paedophiles and it's probably a perversion'. And Nigel finds a legitimizing discourse in the idea of equality and diversity which has, for years now, been permeating organizational spaces: 
... I would begin by talking about difference and saying that, you know, in the culture that I come from difference is good... He might begin to make links but I wouldn't want to alienate ...

This fantasy coming out draws on the discourse of difference and on linguistic constructions used by the lesbian and gay movement so that their own diversity may be recognized and encapsulated in the expression "equality and diversity." Over the years, recognition of differences has become an indicator of social justice and of respect for the rights of citizenship. In organizations, these slogans, which Nigel seems to have assimilated, have been transformed into the policies and practices of diversity management and of the appreciation of differences. Nonetheless, some scholars (Gordon, 1995; Richardson and Morno, 2012; Zanoni, 2010) have been critical of the idea of diversity since, on the one hand, it is exploited, above all, in order to obtain an economic and organizational advantage and, on the other, because it is based on a model which constructs difference - sexual and of gender - as ontology.

Over the years the equality and diversity discourse has drifted into a discourse of assimilation (Richardson, 2004). We detect traces of this shift in the account given by John, a young man of 22 years of age who constitutes himself as gay, using the discursive variation on normality. He is the manager of a fast food outlet in Manchester, where the majority of workers are Muslims. He positions himself as the only gay in the restaurant 
(at least, he presumes as much), in a couple with a boyfriend (like Mike, Roger and Ryan) and in charge of a group of male Muslims. The group of Muslims has asked John the classic heteronormative question: 'do you have a girlfriend?' and after the disclosure of his sexual identity, they have subjected him to a kind of interrogation: 'And a lot of times some of the people they want me to explain to them, like cause its new to them [...] it's something they've never really come across before.'

The possibility of speaking of, discussing and explaining homosexuality can be seen as a step forward when compared to the silence which often surrounds the member of a minority potentially at risk of discrimination. In his account John seems secure, unconcerned by his homosexuality, but perhaps this sense of security is also possible because he positions himself as the manager, in charge of this little world of Muslim men. Thus, it is also his position of power, together with his ethnic background (male and white), which perhaps facilitates this account of self. We might indeed ask ourselves what would occur if John were not in charge of this group and were, moreover, a Muslim. Would it be possible for John to speak so explicitly about the fact that he likes men? But let us listen to John once more as he completes his positioning:

They seem quite interested like, they ask like 'So what do you do then like, you're a man, so what kind of stuff do you do? ... Do you still like show affection to each other? Like do you still have sex? ... I'm like yeah it's just 
normal just as if I was... That's how I explained it. I did, just I do what exactly the same as I would do with a lady but I just do it with a guy, its just, it's the same as a man or woman, its just natural for me, same thing...

John asserts that being gay means being normal because gays do the same things as heterosexuals: eat, drink and there is no difference between the type of sex, which he has with a man and that which he imagines having with a woman. The subtext seems to be the following: the heterosexual world is the normal one, I am the only gay at the restaurant (so I am the one who is different, I distance myself from the norm) and therefore I defend my identity, claiming to be normal like a heterosexual. And this matter puzzled his Muslim colleagues no little:

They were all a bit shocked because I don't know, maybe they have this preconception of what a gay man should be like, like a stereotype, and I don't really fit that stereotype. Like... the typical camp or queen, like go round mincing everywhere and hands waving everywhere (laughs). Er that's not me. I'm quite stern and I move about quite a lot, quite domineering at work because I like to make sure things are done. Erm so they'd never have guessed, ... cause... I seem probably to them quite normal. Like a straight man. 
Normality is inflected according to the model of the heterosexual male: John is not the flamboyant or camp gay who can arouse in others feelings of embarrassment, contempt and shame. He is not the gay who wears high heels, paints his nails and dyes his hair, wears showy clothes and moves about mimicking female poses; he is '...quite normal. Like a straight man'. Managerial skills are described in stereotypical, masculine terms (strict, dominant and dynamic) as dis-identification with the opposite terms associated with the camp gay. In pouring scorn on the camp gay, John constructs his identity as a respectable gay who, being such, can come out. He is the normal gay manager; a camp gay is, on the contrary, abnormal. Before reading these passages we might call to mind Kristeva's theory of abjection (1982), according to which the definition of a coherent identity is based on the existence of the abject, which must be constructed in a repugnant way, so as to allow the stating and legitimation of its opposite.

The construction of a (new) subcategory, that of the camp gay, is used to strengthen the position of the normal gay like a straight man. For John, homosexuality is not a problem, to the point that in the workplace he can speak of it; it can, however, become a problem, when it is embodied in the form of the camp gay or the drag queen, which, when all is said and done, would not be normal. This is a rather limiting interpretation of being camp which precludes potential for criticism inherent in the forms of parody (Butler, 1999). Parody, displayed through the drag performance in Butler's examples (of both the 
drag king and drag queen), has a critical and transgressive potential to question oppressive gender expectations.

John's narrative reflects an integrationist discourse which tends to assimilate gays and heterosexuals. Normalizing logic is based on the idea of a similarity between lesbians/gays and heterosexuals and coincides with 'the emergence of a new citizenship discourse that asserts the "normality" of being gay' (Richardson, 2004: 392) and it is through this call for normality that the integration and social inclusion of gays as respectable citizens (Richardson, 2004) and consequently also as good, professional managers is justified and claimed: alongside the normal gay, now stands the normal gay manager.

The discourse on normality then becomes interwoven with the discourse on being professional, which comes into play to reinforce and discipline John's identity performance, and is evoked when he thinks about a coming out with a customer:

I always act professional to the customers. I can usually tell if a customer's, you know, gay or not, but only going by stereotype, you know like going for the camp ... Where they're like, erm, prancing around. I still just treat them professionally as I would any other customer. 
What comes through here is the conception of the good professional as neutral, impartial, as someone who does not let his emotions show and who separates profession and sexuality (Rumens and Kerfoot, 2009). It is the same separation suggested by the words of Paul, a family doctor, who comments on the possibility of coming out to a patient: ‘...It would be unprofessional of me ... it would be slightly unprofessional for me to say “I'm gay"...' Now, coming back to John's words, here the category of the normal gay also returns: the normal gay manager, as well as doing his job well, assumes postures, demeanours and poses, regulated according to male models; the good, professional manager is not camp or flamboyant. These discursive variations model the physical and impose the related model of maleness/masculinity, but at the same time place John in a strange and contradictory position, in that, in distancing himself from the camp gay, he is denigrating a different form of the gay. We suggest that this different form and positioning can provoke feelings of guilt, because, John is expressing contempt for one of his own (Halperin, 2012).

We wish to conclude our analysis of John's coming out story by imagining a breaking point in his narrative, and a subversion of the heteronormative order. The statement: 'I seem quite normal to them. Like a straight man' appears to sum up the fiction (I seem) combined with the assimilationist ([I am] like) and normalizing discourse, which reinforces the gay vs straight dichotomy. Our suggestion to the reader is to try to exercise the art of parody (Butler, 1999) along with us. For example, we might imagine that a 
heterosexual male, referring to his relations with a group of male workmates, might say: 'I seem quite normal to my colleagues. Like a gay man'. A phrase of this type, which sounds impossible, bizarre and paradoxical, is, for us, a path to follow in the pursuit of a new order, in challenging the heterosexual matrix and heteronormativity, and, therefore, also in supporting social and organizational change.

\section{Conclusions}

Echoing Foucault (1976), we can assert that the stories of the gay men in this study are no more and no less than the consequence of the appearance in the $19^{\text {th }}$ century - in psychiatry, in medicine, in jurisprudence and in literature - of a set of discourses on homosexuality. According to Foucault these discourses permitted the formation of a set of reverse discourses since, in turn, homosexuality 'began to speak in its own behalf, to demand that its legitimacy or "naturality" be acknowledged...' (1976: 101). Since the $19^{\text {th }}$ century homosexuality has continued to speak on its own behalf, it has entered organizations and expressed itself through the words, too, of the participants in this study.

Through the voice of Nigel, some homosexuality discourse uses the words of identity (the appeal of saying 'I am gay'), reinforcing the binary system of the heterosexual matrix through the admission of homosexuality. Nevertheless, the admission of gay identity also has the effect of producing a relation of power and inequality in which the subject was, and is, subordinate to the dominant Other, and is subjected to essentialist 
discourses. Homosexuality has started to 'speak on its own behalf' and has used the language of the relationship of the couple with a boyfriend or with a partner through the voices of Roger, Mike and Ryan. Coming out gives way to a declaration of being in a relationship, which evoke the conventional married family life. This positioning controls other possibilities to perform sexuality. Finally, homosexuality has also continued to narrate its story in the language of diversity (Paul and Nigel) and normality (Nigel). In particular John interpreted himself as being 'not like' the stereotypical gay; he therefore constructed his position through disidentification with the camp gay. In this case there is a normalizing discourse at play, based on the idea that gay people are the same as heterosexuals.

Our work shows that homosexuality discourses have expanded and become more visible, even within heteronormative organizational spaces, and now we can continue the discussion opened by Butler: 'So we are out of the closet, but into what?' We could also ask what new organizational rooms or potential other closets are now occupied by the participants. Was there a new, different, fresh atmosphere outside the closet, or did coming out represent the entry into an organizational space occupied by powerful disciplining laws that continue to sustain the binaries and normative discourses? We propose that the discursive variations we have outlined speak back to heteronormativity but they don't question the binary structure also embedded in these reverse discourses. Instead, discourses shared in this paper perpetuate the binarisms (straight vs gay, 
heterosexual vs homosexual) by using categories created to qualify and disqualify homosexuality (see Foucault, 1976). In line with some recent literature that problematize the new-born 'gay-friendly' organizations (Rumens, 2014; Rumens and Broomfield, 2014; Williams et al., 2009), our research reveals how coming out (one of the column/pillar of inclusive and tolerant organizations ${ }^{5}$ ), can be a slippery and ambiguous road, that we could not unproblematically valorise and address. We have illustrated in this paper how coming out functions as a discourse which, together with contextualised heteronormativity, disciplines (sexual) identities by defining for example what is the normal (and vice versa what is the abnormal) expression of homosexuality: coming out is a tricky discursive construction. We believe that the complex and multifaceted discursive constructions associated with and constituting coming out should be investigated further. We call for more sophisticated research into the moral, ontological, normative and political nuances of coming out in general and in the workplace in particular.

In conclusion, coming out of the closet is equivalent to entering a problematic new space. As Chambers (2007) states, we comprehend sexuality through heteronormativity and through the fact that we assume that everybody is straight, but when that presumption proves wrong, heteronormativity then requires that those who are not straight pretend to

\footnotetext{
${ }^{5}$ It is significant that in Williams et al.'s (2009) study of US LGB employees participants defined the possibility to openly disclose themselves as one of the main characteristic of a gay-friendly organization.
} 
be so (so that we can continue to presume that they are straight) or declare explicitly their deviation from the norm (in other words, they continue to come out). The declaration may use different intonation, language, words, discourses, and practices but this declaration functions as the sign that heteronormativity is at work. In this way coming out confirms itself as a discourse, which supports and reinforces heterosexual privilege: heterosexuals do not need to come out. Perhaps, then, to move beyond the sexuality binarism it is necessary to 'subvert heteronormativity [and thereby] render sexuality less legible, to undermine the practices of reading sexuality produced by heteronormativity' (Chambers, 2007: 673).

From the political and activist perspective, gay activists endorse coming out as a device to defend and acquire rights for LGBT people equal to heterosexual individuals. This position, which supposes the existence of a coherent and consistent gay and lesbian identity on which to base political actions (Motschenbacher and Stegu, 2013), is criticized by queer activists and theorists trying to disrupt or subvert sex and identity boundaries and deconstruct identity categories (Gamson, 1995). Our work is aligned with this second view and we feel that in these pages we have contributed to the project of subverting heteronormativity. As asserted by Spivak (1989), a fundamental lesson of poststructuralism is that while we ourselves can only assume a position of strategic essentialism we must work relentlessly to unmask the ways essentialism works and its effects. This can mean that we keep using categories (race, gender, sexual identity), but 
at the same time strive continuously to problematize them: to criticize constantly stable and disempowering structures in order not to inhabit them without critical reflection and modified discursive practices (see also Spivak, 1993). Conceived in this way, our work as researchers becomes more ethical and less definitive, fixed, and secure.

\section{References}

Austin, J.L. (1962) How to Do Things with Words. MA: Harward University Press.

Bouzianis B., Malcolm, J.P. and Hallab, L. (2008) Factors associated with sexual identity disclosure in the workplace by gay men and lesbians: A couples study. Gay \& Lesbian Issues and Psychological Review, 4,3, 166-175.

Britzman, D. (2000) 'The Question of Belief': Writing poststructural ethnography. In St. Pierre, E.A. and Pillow, W. (eds) Working the Ruins: Feminist Poststructural Theory and Methods in Education. New York: Routledge.

Butler, J. (1991) Imitation and Gender Insubordination. In Fuss, D. (ed) Inside/Out: Lesbian Theories, Gay Theories. New York: Routledge pp.13-31.

Butler, J. (1997a) Excitable Speech. A Politics of the Performative. London: Routledge. Butler, J. (1997b) The Psychic Life of Power. Stanford CA: Stanford University Press. Butler, J. (1999) Gender Trouble. Feminism and the Subversion of Identity. Tenth Anniversary Edition. New York: Routledge. 
Button, S.B. (2004) Identity management strategies utilized by lesbian and gay employees: A quantitative investigation. Group \& Organization Management, $29,4,470-494$.

Chambers, S.A. (2007) 'An incalculable effect': Subversion of heteronormativity. Political Studies, 55,3, 657-679.

Chirrey, D.A. (2003). 'I hereby come out': What sort of speech act is coming out? Journal of Sociolinguistics 7(1): 24-37.

Chirrey DA (2011) Formulating dispositions in coming out advice. In Discursive Studies, 23,3, 283-298.

Clair, J.H., Beatty, J.E. and MacLean, T.L. (2005) Out of sight but not out of mind: Managing invisible social identities in the workplace. Academy of Management Review, 30,1, 78-95.

Colgan, F., Creegan C., McKearney, A. and Wright T. (2008) Lesbian workers: Personal strategies amid changing organizational responses to sexual minorities in UK workplaces. Journal of Lesbian Studies, 12,1, 31-45.

Colgan, F. and Wrigh, T. (2011) Lesbian, gay and bisexual equality in a modernizing public sector 1997-2010: Opportunities and threats. Gender, Work \& Organization, 18,5, 548-570. 
Croteau, J.M., Anderson, M.Z., and VanderWal., B.L. (2008) Models of Workplace sexual identity disclosure and management: Reviewing and extending concepts. Group \& Organization Management, 33,5, 532-565.

Day, N.E. and Schoenrade, P. (2000) The relationship among reported disclosure of sexual orientation, anti-discrimination policies, top management support and work attitudes of gay and lesbian employees. Personnel Review, 29,3, 346-363.

Davies, B. and Harré, R. (1999) Positioning and Personhood. In Harré, R. and Van Langenhove, L. (eds) Positioning Theory. Oxford: Blackwell.

Driscoll JM, Kelley FA and Fassinger R (1996) Lesbian identity and disclosure in the workplace: Relation to occupational stress and satisfaction. Journal of Vocational Behavior 48(2) 229-42.

Douglas Creed, W.E. and Scully, M.A. (2011) Songs of ourselves. Employees deployment of social identity in workplace encounters. Journal of Management Inquiry, 20,4, 408-429.

Dow, B.J. (2001) Ellen, television, and the politics of gay and lesbian visibility. Critical Studies in Media Communication, 18,2, 123-140.

Duggan, L. (2002) The new homonormativity: The sexual politics of neoliberalism. In Castronovo, R. and Nelson, D.D. (eds) Materializing Democracy: Towards a Revised Cultural Politics. Durham, NC: Duke University Press.

Ford, J. (2006) Discourses of leadership: Gender, identities and contradictions in a UK 
public sector organization. Leadership, 2,1, 77-99.

Foucault, M. (1979) The History of Sexuality, Vol. 1. London: Allen Lane.

Gee, J.P. (2011) An Introduction to Discourse Analysis. Theory and Methods. New York : Routledge.

Gubrium, J.F. and Holstein, J.A. (2003) Postmodern Interviewing. New York: Sage.

Halpering, D.M. (2012) How to Be Gay. Cambridge, Massachuset: Belknap Press.

Jackson, A.Y. and Mazzei, L.A. (2012) Thinking with Theory in Qualitative Research. London: Routledge.

MacLure, M. (2003) Discourse in Educational and Social Research. Buckingham: Open University Press.

Ozturk, M.B. (2011) Sexual orientation discrimination: Exploring the experiences of lesbian, gay and bisexual employees in Turkey. Human Relations, 64,8, 10991118.

Parker, I. (2005) Qualitative Psychology. Introducing Radical Research. Maidenhead: Open University Press.

Prasad, A. (2012) Beyond analytical dichotomies. Human Relations, 65,5, 567-595.

Richardson, D. (2004) Locating sexualities: From here to normality. Sexualities, 7,2, 391-411.

Roulston, K. (2010) Reflecting Interviewing: A Guide to Theory and Practice. London: Sage. 
Rumens, N., and Kerfoot, D. (2009) Gay men at work: (Re)constructing the self as professional. Human Relations, 62,5, 763-786.

Sedgwick, E. (1990) Epistemology of the Closet. Berkeley: University of California Press.

Skidmore, P. (2004). A legal perspective on sexuality and organization: A lesbian and gay case study. Gender, Work \& Organization, 11,3, 229-253.

Spivak, G.C. (1989) In a word. differences: A Journal of Feminist Cultural Studies, 1,2, 124-156.

Spivak, G.C. (1993) Outside in the teaching machine. New York: Routledge.

Strycker, S. (2006) (De)Subjugated Knowledges: An Introduction to Transgender Studies. In Stryker, S. and Stephen, W. (eds) The Transgender Studies Reader. New York: Routledge.

Tanggaard, L. (2009) The research interview as a dialogical context for the production of social life and personal narratives. Qualitative Inquiry, 15,9, 1498-1515.

Ward, J. and Winstanley, D. (2003) The absent present: Negative space within discourse and the construction of minority sexual identity in the workplace. Human Relations, 56,10, 1255-1280.

Warner, M. (1993) Fear of a Queer Planet: Queer Politics and Social Theory. Minneapolis: University of Minnesota Press.

Willis, P. (2012) Witnesses on the periphery: Young lesbian, gay, bisexual and queer 
employees witnessing homophobic exchanges in Australian workplaces. Human Relations, 65,12, 1589-1610.

Woltersdorff, V. (2012) Paradoxis of precarious sexualities. Cultural Studies, 25,2, 164182. 